\title{
Primary pigmentary degeneration of the retina and acromegaly in a case of pituitary adenoma
}

\author{
J. M. SMAIL
}

Shrewsbury

Primary pigmentary degeneration of the retina has been linked with pituitary dysfunction since the complete clinical picture of primary dystrophy, hypogenitalism, obesity, polydactyly, and mental deficiency was fully documented several years ago (Laurence and Moon, I 866; Biedl, I 922). This syndrome, known as the Laurence-Moon-Biedl syndrome, typifies the increasing tendency to associate retinal pigment dysplasia with endocrine dysfunction.

The intermediate lobe of the pituitary gland secretes a hormone, melanophore-stimulating hormone $(\mathrm{MSH})$, which has been shown to have a marked effect on the skin colour of frogs (Hogben, I 924) and to increase the skin pigmentation in human beings (Lerner and McGuire, I96I). While the above actions of MSH are accepted, this hormone has not been shown conclusively to have any effect on the pigment cells of the choroid or retinal pigment epithelium. In the hope that pituitary extracts containing MSH might be beneficial to the retina affected by primary pigmentary degeneration, several workers have used such extracts for therapeutic purposes. Many authors have claimed favourable results* while a considerable number of other workers have found no such improvement. $\dagger$ It is not within the scope of this paper to enter into this controversy.

One would expect that, if MSH has any controlling effect whatever on the retinal pigment epithelium, cases of retinal pigmentary dysplasia would occur from time to time in patients suffering from pituitary tumours, especially those tumours associated with pituitary dysfunction. The commonest of these is the chromophobe adenoma. A thorough search through the neuro-ophthalmic literature has failed to reveal a single case. It seems worth while therefore to record a case in which primary pigmentary degeneration of the retina occurred in a man with a pituitary chromophobe adenoma in which the pars intermedia appeared to have been totally destroyed.

\section{Case report}

A man aged 44 years was admitted to the Midland Centre for Neurosurgery and Neurology, Smethwick, on July 2 I, 1968.

About ro years previously his vision had started to deteriorate. Objects to each side became progressively more difficult to see and he could only be sure of his sight when observing objects directly in front. He had also become impotent over the past year. For about 6 months his 
fingers and hands had increased in size, and his feet were also larger. He began to have headaches, $\frac{\sqrt[0]{3}}{3}$ mainly in the frontal region, about 2 months before admission, and he started to perspire freelyo from about the same time.

PREVIOUS MEDICAL HISTORY

Apart from bilateral inguinal hernias which had been repaired surgically, he had never been illo before.

FAMILY HISTORY

He was married and had two sons aged 25 and 19 years. His wife and children were well and therewas no relevant family history.

PHYSICAL EXAMINATION

He was a heavily built middle-aged man. His face was long with coarse features and his tongue large. His speech was laboured and not clearly understandable. He had large hands and feetiv and there was clubbing of the fingers. There was generalized weakness in all four limbs and his movements were sluggish.

The corrected visual acuity was right eye-counting fingers, left eye-6/6o. Both fundi showedc the typical changes of primary retinal pigmentary dysplasia of retinitis pigmentosa type. These changes involved the whole of both fundi apart from the posterior poles. The optic discs were of good colour, considering the extensive pigment changes and the arterial narrowing.

The visual fields were plotted on the Goldmann perimeter and revealed tubular fields in both $\vec{N}$ eyes reduced to $3^{\circ}$ from fixation with a white IV 4 target (Fig. I).

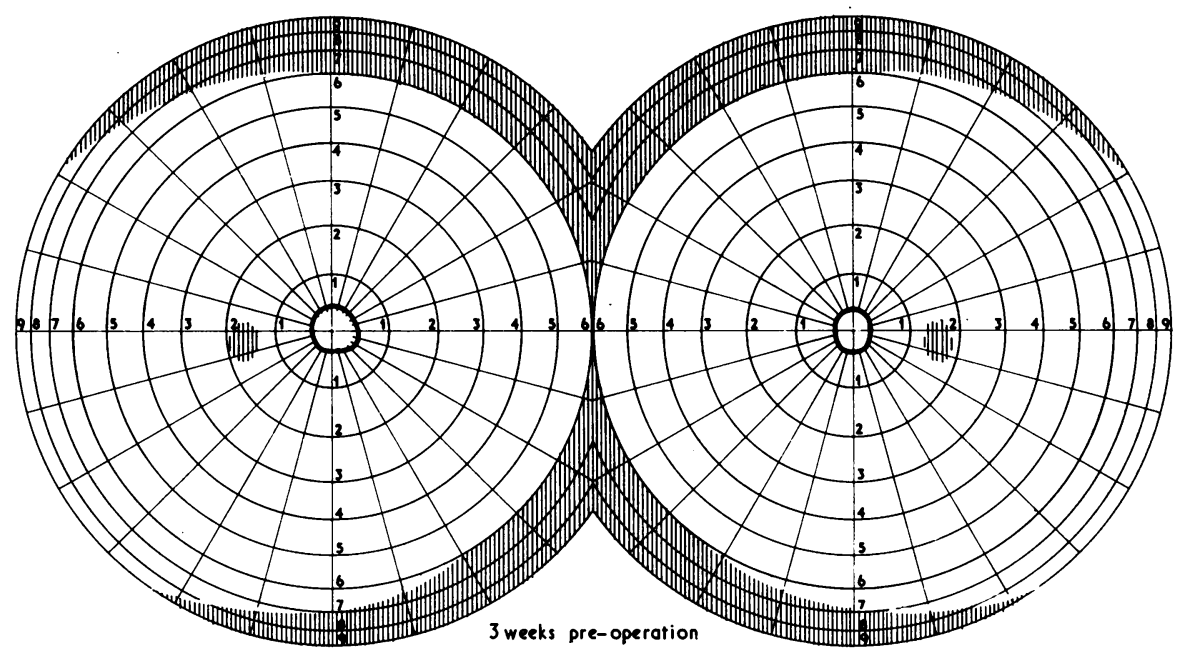

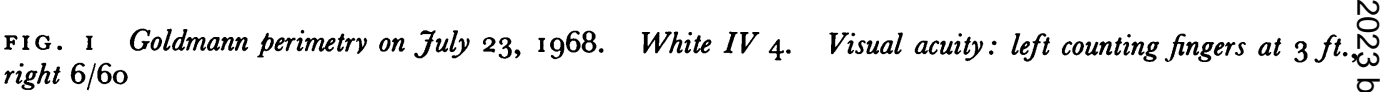

\section{LABORATORY INVESTIGATIONS}

17 oxosteroids $14 \mathrm{mg} . / 24 \mathrm{hrs}$; protein-bound iodine $3.4 \mathrm{mg}$./ 1 oo ml.; blood sugar (random) roo mg. I0o ml.; urea $20 \mathrm{mg}$./ $100 \mathrm{ml}$.; haemoglobin $14.4 \mathrm{~g}$./100 ml.; erythrocyte sedimentation rate (Wester-ö gren) $26 \mathrm{~mm}$./Ist $\mathrm{hr}$; white blood cells $5000 /$ cubic $\mathrm{mm}$. (neutrophils 52 per cent., lymphocytes $4^{\text {I }}$ per cent.; monocytes 6 per cent.; basophils I per cent.).

Wassermann reaction and Kahn test negative.

Cerebrospinal fluid protein $78 \mathrm{mg} . / 100 \mathrm{ml}$. 
$X$ rays-C-Chest: Showed some scarring of right apex due probably to healed tuberculosis.

Skull: Showed moderate ballooning of the sella turcica with thinning of the dorsum sellae and erosion of the posterior clinnid processes (Fig. 2).

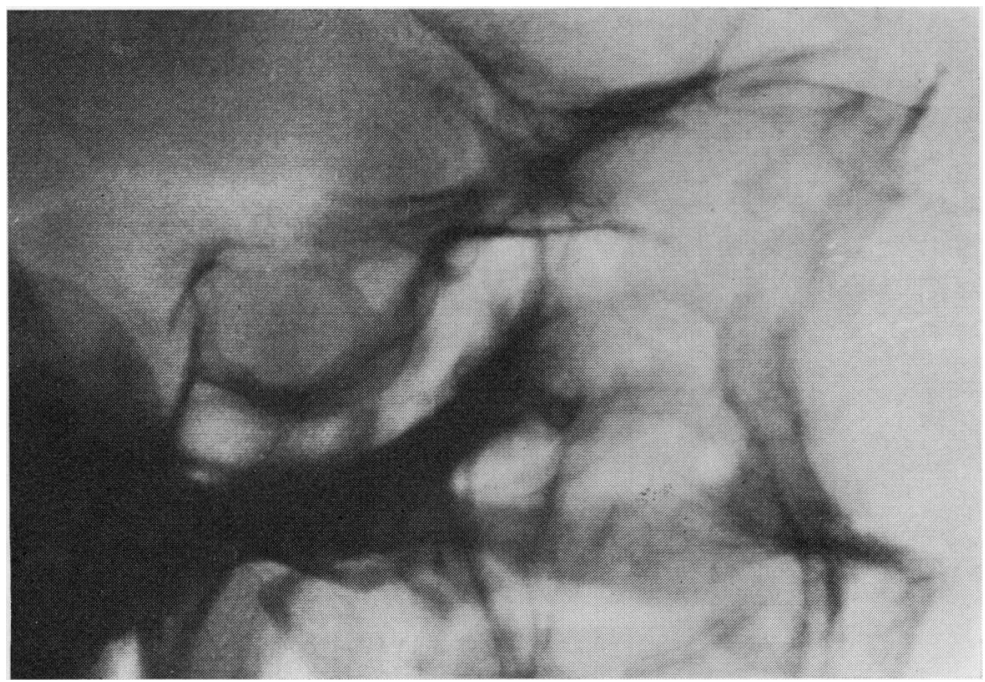

FIG. 2 Lateral $\mathrm{x}$ ray of skull, showing ballooning of the sella turcica, thinness of the dorsum sellae, and erosion of the posterior clinoid processes

Carotid angiogram: Revealed a tumour having a small suprasellar extension with no evidence of further extension laterally or in any other direction.

Electroencephalographic findings were a few theta waves at 5 or 6 cycles per second of slightly higher amplitude than the background activity in the fronto-temporal regions, $\mathrm{L}>\mathrm{R}$, in the transverse position after overbreathing.

OPERATION

On August 14, I968, a large irregular dumb-bell shaped pituitary tumour was completely removed by frontal craniotomy. The upper part of the tumour lay above the diaphragma sellae and was not encapsulated. This was possibly compressing the left optic nerve only very slightly and the right one not at all. The lower part of the tumour was successfully excised from below the diaphragma sellae and the hypophyseal remains also removed.

\section{PATHOLOGICAL REPORT}

The specimen consisted of several fragments which were removed at the operation. All the material was examined.

\section{Histology}

The major part of the specimen consisted of a chromophobe adenoma, mostly of papillary pattern, but with occasional more solid areas (Fig. 3, overleaf). The usual amount of nuclear pleomorphism was evident. Compressed but recognizable anterior lobe tissue appeared in one or two sections, together with degenerate foci containing cholesterol crystals and giant cells (Fig. 4, overleaf). There was also one single small fragment of posterior lobe, together with a collection of tiny colloid-filled cysts, but no recognizable intermediate lobe tissue.

POST-OPERATIVE PERIOD

The patient made a good recovery from the operation. It was necessary to prescribe pituitary snuff each night since he had signs of diabetes insipidus; and cortisone $25 \mathrm{mg}$. twice daily and phenobarbitone $30 \mathrm{mg}$. twice daily were also prescribed in an attempt to avert epilepsy. One week post- 


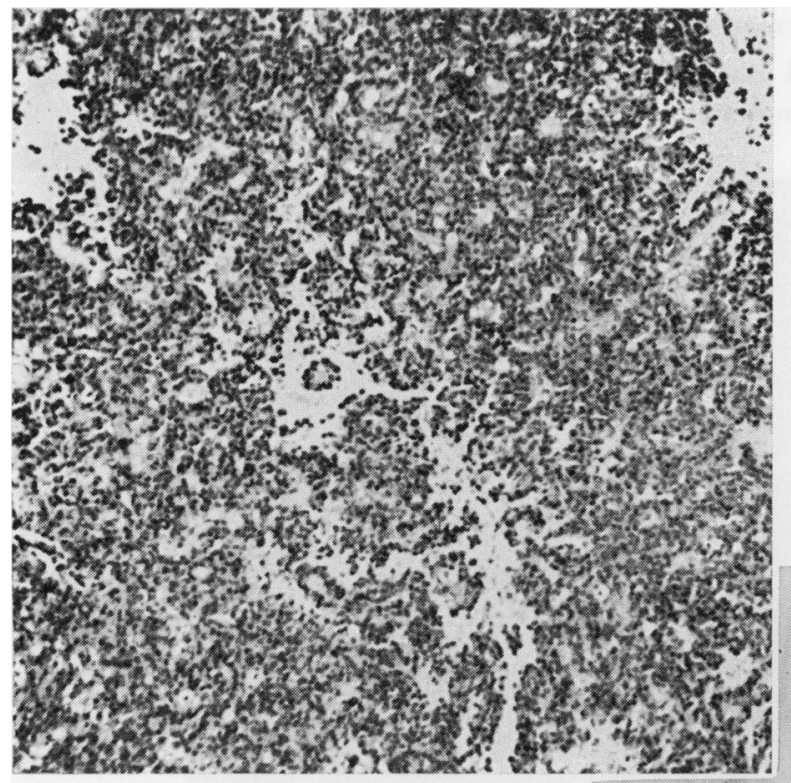

FIG. 3 Section of pituitary biopsy, showing typical chromophobe adenoma of largely papillary structure. The gaps are artefacts. Haematoxylin and eosin. X I I 2

FIG. 4 Two cysts at one corner of the biopsy resembling those usually seen in the intermediate lobe area. Haematoxylin and eosin. $\times 1 \mathrm{I} 2$

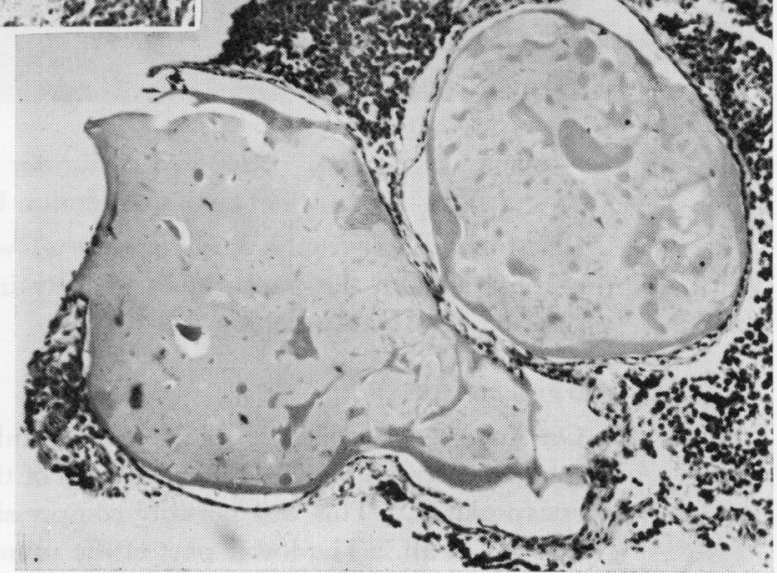

operatively the corrected visual acuity was $6 / 18$ in the right eye and $6 / 12$ in the left. The Goldmann fields (Fig. 5, opposite) had increased to:

Right- $10^{\circ}-11^{\circ}$ from fixation to White IV $4,4^{\circ}$ from fixation to White II 2.

Left- $9^{\circ}$ from fixation to White IV $4,4^{\circ}$ from fixation to White II 2.

The patient was discharged from hospital on August 23, 1968.

In July, I969, he developed cerebrospinal rhinorrhoea and was re-admitted to the Neurosurgical Centre.

On September 10, 1969, a fascia lata graft to the wall of the anterior fossa and posterior frontal sinus was carried out. This successfully cured the cerebrospinal rhinorrhoea.

\section{Progress}

While he was convalescing the following tests were carried out:

Electro-oculogram Very irregular movements

Right eye-Index approx. Iooo per cent.

Left eye-Index impossible to measure but flat. 


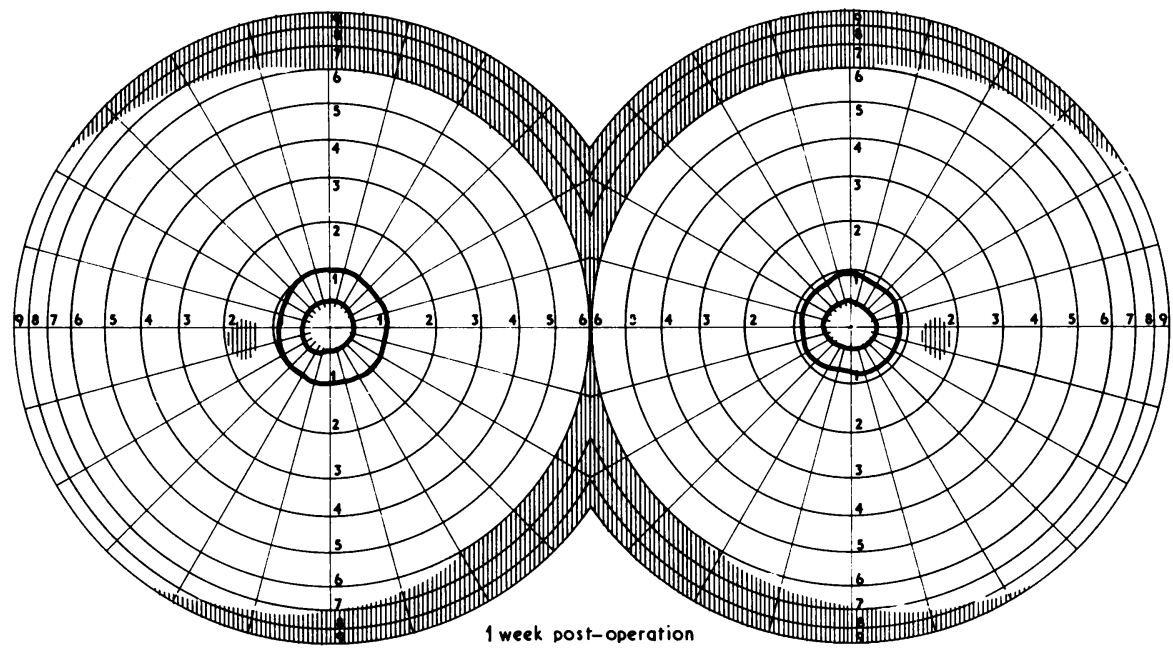

FIG. 5 Goldmann perimetry on August 20, 1968 . White $I_{4}$ and II 2. Visual acuity: left 6/12, right 6/18

Dark adaptation

Electroretinogram

Goldmann perimetry

(Fig. 6)
Stopped after 16 minutes. Lowest reading $10^{5}$.

Tracing extinguished in both eyes.

Right field $10^{\circ}-\mathrm{II}^{\circ}$ from fixation to White IV 4. $4^{\circ}$ from fixation to White II 2.

Left field $9^{\circ}$ from fixation to White IV 4 . $4^{\circ}$ from fixation to White II 2.

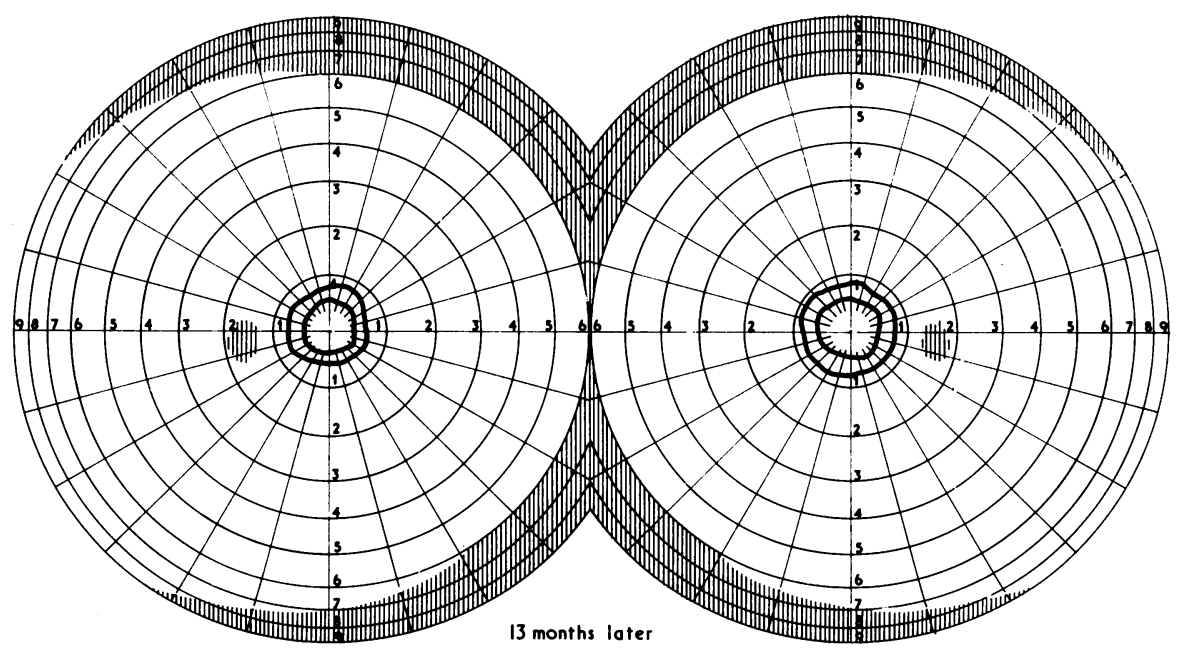

FIG. 6 Goldmann perimetry on September $9,{ }_{1969}$. White $I V 4$ and II 2. Visual acuity: left 6/9, right 6/1 2

\section{Fundus photography}

The left fundus on September 18 , 1969, is shown in Fig. 7 (overleaf).

RESULT

The patient's appearance in March, 1971, is shown in Fig. 8 (overleaf). 


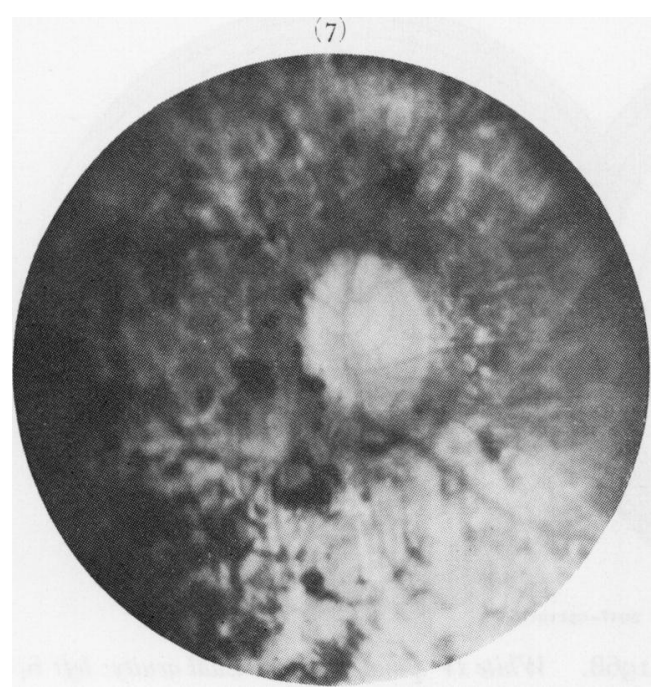

Fig. 7 Left fundus on September 18, 1969. The right fundus appeared almost identical

FIG. 8 Patient's appearance at follow-up in March, I97 I

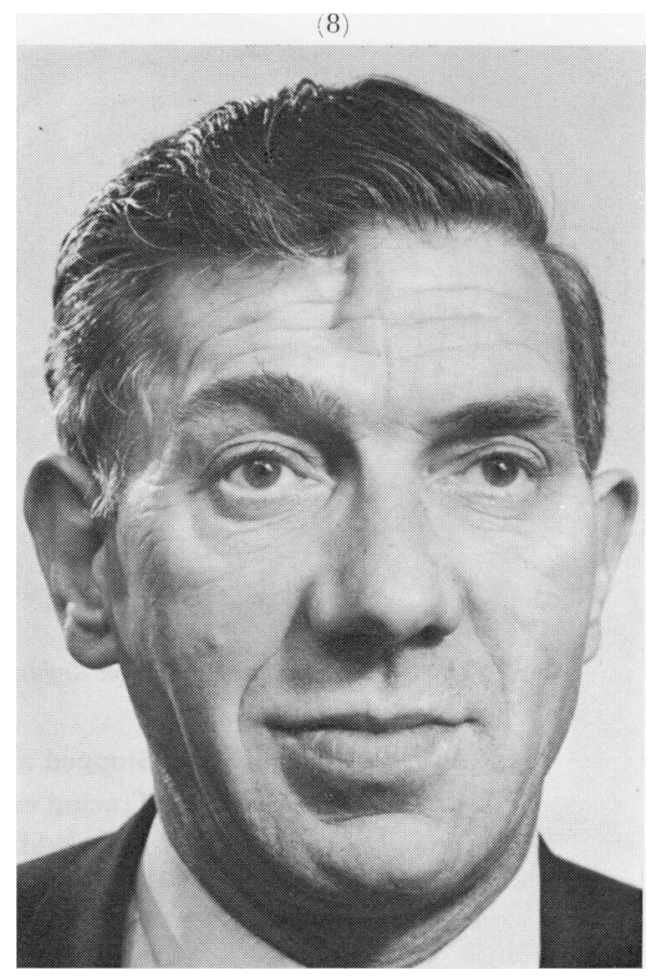

\section{Discussion}

Most chromophobe adenomas produce clinical signs of hypopituitarism, but a small number manifest with signs of acromegaly, as in this case, with Cushing's disease, or with the lactation syndrome (Cogan, I966).

It is possible that the occurrence in the same patient of pituitary dysfunction and primary pigmentary degeneration of the retina is pure chance. However, several authors, whose work is referred to above, believe there is a real link between the intermediate lobe of the pituitary and the retina. If this is so, then retinal degeneration of pigmentary type should occur in at least a small number of cases of pituitary hypofunction, especially those with intermediate lobe destruction. The above case illustrates just such an occurrence.

Reference has previously been made to reports claiming therapeutic success with pituitary extracts. Assessment of these reports is made difficult since the pituitary extracts used were relatively impure and only in 1960 did $\mathrm{MSH}$ become available in purified form (Lerner and McGuire, I96 I). Also, the improvement claimed in these cases relied mainly on subjective tests, which are often unreliable. In the present case, the field improvement may have been more apparent than real for the same reason.

\section{Summary}

The possible relationship between melanophore-stimulating hormone and the pigment cells of the retina and choroid is discussed. A case of primary pigmentary degeneration of the retina occurring in a patient with chromophobe adenoma of the pituitary in which the pars intermedia was destroyed is recorded. 
I should like to thank Mr. J. Snall and Mr. M. Ropz:-Hıll for par nitting me to record this case, and to Dr. Salmon for his help with the pathology.

\section{References}

Basile, G. B. (1939) Ann. Ottal. clin. Ocul., 67, 41 2

BEAUVIEUX, FERron, and houssin (1950) Bull. Soc. Ophtal. Fr., p. 228

BIEDL, A. (1922) Dtsch. med. Wschr., 48, I630

Blobner, F. (1937) Klin. Mbl. Augenheilk., 98, 289

BUSCHKE, W. (1934) Klin. Wschr., 13, I 785

CAMPBEll, D. R., and GebertT, s. (1955) Trans. ophthal. Soc. U.K., 75, 667

COGAN, D. G. (1966) "Neurology of the Visual System", p. 226. Thomas, Springfield, Ill.

Dimitriu, T. (195I) Bull. Soc. héllen. Ophtal., 19, 386

FRANçors, J. (1950) Bull. Soc. belge Ophtal., no. 95, p. 426

Gordon, D. M., and BURKe, G. E. (1958) Amer. J. Ophthal., 45, 666

GUNDAROVA, R. A., SGHEKINA, A. N., and Kortikova, E. A. (I96o) Vestn. Oftal., 73, no. 4, p. 37

HOGBEN, L. T. (1924) "The Pigmentary Effector System". Oliver and Boyd, London

JORES, L. (1933) Klin. Wschr., 12, I 559

LAURENCE, J. z., and moon, R. c. (1866) Ophthal. Rev., 2, 32

LERNER, A. B., and McGUIRE, J. s. (I96I) Nature (Lond.), 189, I 76

MOREU GONZALEZ POLA, A. (1950) Arch. Soc. oftal. hisp.-amer., ro, $45^{8}$

mussio-fournier, J. C., conti, o., gonzales VANRell, F., and CARriQuiry, P. (1949) Bull. Acad. nat. Méd. Paris, 133, 103

MUTCH, J. R., and MACKAY, D. (1943) Brit. J. Ophthal., 27, 434

NAGdasaeva, A. L., and savitskaya, N. F. (1960) Vestn. Oftal., 73, no. 4, p. 35

RAMA, G. (1952) Rass. ital. Ottal., 21, 143

ROKITSKAYA, L. v., and ADISHRNI-ZADE, R. F. (I96I) Oftal. Zh., 16, no. 5, p. 28I

SCARdacGione, M. (1938) Boll. Oculist., 17, 755

(I94I) Ibid., 20, 108

STEFfensen, E. H., and kUkORA, J. (1951) Amer. J. Ophthal., 34, I665

velter, e., Desvignes, P., and salmon (1950) Bull. Soc. Ophtal. Fr., p. 9 